\title{
ESTIMATION OF BASIC GEOMETRIC AND HYDRAULIC CHARACTERISTICS OF NATURAL TORRENT BEDS
}

\author{
Matúš Jakubis ${ }^{1}$, Mariana Jakubisová2 \\ ${ }^{1}$ Department of Forest Harvesting, Logistics and Amelioration, Faculty of Forestry, Technical University in Zvolen, \\ T. G. Masaryka 24, 96053 Zvolen, Slovak Republic \\ ${ }^{2}$ The Borova Hora Arboretum of the Technical University in Zvolen, Borovianska cesta 66, 96053 Zvolen, Slovak \\ Republic
}

Link to this article: https://doi.org/10.11118/actaun202068050841

Received: 15. 7. 2020, Accepted: 25. 9. 2020

To cite this article: JAKUBIS MATÚŠ, JAKUBISOVÁ MARIANA. 2020. Estimation of Basic Geometric and Hydraulic Characteristics of Natural Torrent Beds. Acta Universitatis Agriculturae et Silviculturae Mendelianae Brunensis, 68(5): 841-849.

\begin{abstract}
Many mountainous regions and their watersheds lack the mathematical description of their hydraulic geometry such as the High Tatras region in Slovakia. Therefore, the aim of the paper is to determine the geometric and hydraulic characteristics of natural torrent beds and to propose a regional equations of mountain watersheds for the High Tatras region. In the paper is also proposed a new equation to determine the relationships between the watershed area and the geometric characteristics of flow profiles. Derived regional equations can help in nature-friendly and ecological shaping and dimensioning of channel cross sections in torrent control designing. The research was conducted in 26 natural torrents and their watersheds on the reference sections and profiles under the sediment source zones. Two different regression equations to determine the regional relationships (hitherto used without asymptote and newly proposed with asymptote) were compared. The analyses showed a strong correlation relationship between watershed area $A_{w}\left(\mathrm{~km}^{2}\right)$ and bankfull geometric characteristics of natural cross-sections: width of the channel inside the banks $B_{b f}(\mathrm{~m})$, mean channel depth $H_{b f}(\mathrm{~m})$, channel cross-section area $A_{b f}\left(\mathrm{~m}^{2}\right)$ and hydraulic characteristic - bankfull discharge $Q_{h f}\left(\mathrm{~m}^{3} \cdot \mathrm{s}^{-1}\right)$. These relations were tested by t-test and Shapiro-Wilk test. The determination coefficient $\left(\mathrm{R}_{1}^{2}\right)$ for the relationships without asymptote ranged between $\mathrm{R}_{1}^{2}=0.919$ and $\mathrm{R}_{1}^{2}=0.972 ; \mathrm{p}_{1}-$ values from Shapiro-Wilk test ranged between $p_{1}=0.0359$ and $p_{1}=0.8027$. The determination coefficient $\left(R_{2}^{2}\right)$ for the relationships with asymptote ranged between $R_{2}^{2}=0.952$ and $R_{2}^{2}=0.974 ; p_{2}$ - values from Shapiro-Wilk test ranged between $p_{2}=0.0221$ and $p_{2}=0.8617$. At the same time, we tested and confirned the hypothesis that the correlation coefficients $R_{1}$ from equation without the asymptote are only randomly different from the correlation coefficients $R_{2}$ from equation with the asymptote and the difference between these coefficients is also random. Derived regional equations make it possible to the gradual creation of hydrologic landscape regions in the SR. They can be also used as a valuable input to the ecological cross sections designing in torrent control and revitalization for the regions with a similar natural conditions.
\end{abstract}

Keywords: bankfull characteristics, watercourses morphogenesis, High Tatras, Slovakia 


\section{INTRODUCTION}

The total length of the watercourses in the Slovak Republic (SR) is of $61,147 \mathrm{~km}$. These watercourses are mostly managed by state organizations which fall under the Ministry of Environment of the SR and the Ministry of Agriculture and Rural Development of the SR. Approximately 24,000 km of watercourses (39.25\%) are of a torrent nature and $19,412 \mathrm{~km}$ of these torrents (31.75\% from total watercoure length of SR) are managed by state forestry organizations. The torrents found in geomorphological units with similar geological and other natural characteristics of the watersheds (landform, climate, vegetation), show a similar process of morphogenesis, i. e. a long-term natural development of the beds. There are several reasons why to study a longterm morphogenesis of torrent beds and regional hydraulic geometry of mountain torrents and watersheds. The first is the possibility to use the results in practice (design of cross sections in torrent control within the framework of flood protection, erosion control, torrent revitalization, natural torrents management, etc.). In the SR, all torrent watersheds occur in protected areas (national parks, protected landscape areas). This fact should be taken into account during all interventions into torrent beds and watershed because they all have specific natural characteristics. These tasks need to be addressed sensitively and ecologically, especially in protected areas such as the Tatra National Park. Research of regional hydraulic geometry provides important information on the particular stages of torrent beds designing. The fact that this problem has not been sufficiently solved in the SR encourages this type of research. Powel et al. (2004) indicates that in the USA, several decade-old regional equations of hydraulic geometry are used in designing and revitalization of watercourses. Regional equations of hydraulic geometry are unsuitable for existing conditions of watercourses and watersheds. Using these equations may cause various errors in designing the watercourses control and revitalization, with a negative ecological and environmental effect on the landscape. Howell (2009) suggests that regional hydraulic curves are especially useful in stream restoration projects, where the stream is so degraded that natural bankfull channel geometry can no longer be determined and no reference thereto is available. Regional curves can be used also in projects such as road, bridge and culvert construction. Wilkerson (2008) states that this information is essential for planners, engineers, geomorphologists, environmentalists, agricultural interests, developments situated on flood-prone lands, and others interested in floods and flooding. Regional curves should be applied only to projects within the same geographic region or in a region with the same hydraulic geometry curves (Howell, 2009). Wilkerson (2008) noted that physiographic region is a region, within which all parts are similar in geologic structure and climate, and which has a unified geomorphic history and its relief features differ significantly from those of adjacent regions. Regional equations represent relationships between geomorphologic and hydrologic characteristics of watershed and geometric and hydraulic characteristics of channel profile. There are two types of channel and watershed regional equations which are based on the theory of hydraulic geometry:

1. at $-\mathrm{a}-$ station with variations at a particular cross section and

2. downstream with variations along the length of the watercourse (more detailed Leopold et al., 1992; Alexander et al., 2009; David et al., 2010; Julien, 2014; Gleason and Wang, 2015).

Blackburn-Lynch et al. (2017) mention the basic downstream regional hydraulic geometry equations:

$W_{b k f}=a A_{w}^{b}$,

$D_{b k f}=c A_{w}^{d}$,

$A_{b k f}=e A_{w}^{f}$

$Q_{b k f}=g A_{w}^{h}$,

where:

$W_{b k f}$ - the width of the bed inside the banks (m); $D_{b k f}$-mean depth of the bed $(\mathrm{m}), A_{b k f}\left(\mathrm{~m}^{2}\right)$-channel crosssection area, $Q_{b k f}\left(\mathrm{~m}^{3} . \mathrm{s}^{-1}\right)$ - bankfull discharge, $A_{w}\left(\mathrm{~km}^{2}\right)$ - the watershed area; $a, c, e, g$ - empirically derived values of absolute coefficients; $b, d, f, h$ - empirically derived values of regression coefficients.

The problems of regional equations and their use in practice was analyzed by many authors, especially in USA. A detailed overview of the results of published articles has been summarized by Bieger et al. (2015) and Blackburn-Lynch et al. (2017). Torrents generally have three characteristics sections:

1. section with sediment formations (source zone),

2. zone of sediment transport (transport zone) and

3. sediment accumulation zone.

Boundaries between these zones can not be determined precisely, they vary depending on discharge and other factors. The shape of natural torrent beds in each zone also varies. This research paper focuses on developing relationships between watershed area and geometric and hydraulic characteristics of natural torrent beds without direct human interventions. Derived regional equations can help in nature-friendly and ecological shaping and dimensioning of channel cross sections in torrent control designing, flood and erosion control and torrent revitalization in regions for which they were derived and could be modified to be applied for similar regions in Europe. 


\section{MATERIALS AND METHODS}

Analyzed torrents and watersheds are located in the Tatra National Park (TNP) in the geomorphological unit of Tatry, the subunit of Východné Tatry, the part of High Tatras and the geomorphological unit of Podtatranská kotlina, the subunit of Tatranské predhorie (Fig. 1) at altitudes from 860 to $2654 \mathrm{~m}$ a.s.l. High Tatras are the highest mountains in the Slovak Republic.

Between 2016 and 2019, twenty-six torrents with enclosing channel profiles near the southern border of TNP (near the northern border of the geomorphological unit of Podtatranská kotlina) were analyzed. Analyzed torrents are situated in two main river watersheds, Váh and Poprad. The watershed areas of 26 analyzed torrents range from $A_{w}=0.25 \mathrm{~km}^{2}$ (Važecký) to $A_{w}=19.34 \mathrm{~km}^{2}$ (Poprad) with the median $A_{w}=3.21 \mathrm{~km}^{2}$. The discharges $Q_{100}$ range from $Q_{100}=1.5 \mathrm{~m}^{3} \cdot \mathrm{s}^{-1}$ (Važecký) to $Q_{100}=35.7 \mathrm{~m}^{3} \cdot \mathrm{s}^{-1}$ (Biely Váh) with the median $Q_{100}=10.25 \mathrm{~m}^{3} \cdot \mathrm{s}^{-1}$ (Tab. I). The torrents of High Tatras are typical mountain torrents with frequent and rapid changes in discharges, sediments formation, transport of these sediments and their accumulation. Geological structure of the analyzed area is complicated. Three main building blocks can be distinguished in High Tatras: a crystalline core, mountain ranges and sedimentary cover and flysch fill adjacent depressions. Crystalline core appears on a large part of the ridge and on the southern slopes of the mountains. In the higher parts of watershed migmatites - porphyritic granites and granodiorites occur. In the eastern part of High Tatras, from the highest to central position porphyric granodiorites to granites, hercynian, occur in a continuous strip. The lower parts of the analyzed watersheds is formed by bedrock flysch - sandstones and calcareous claystones. As for soil types, in higher elevations Lithic Leptosols and other (nonrendzic) Leptosols are dominant, in lower positions, Haplic Podzols to Humic Podzols are most frequent soil types. From the aspect of hydrological efficiency the soils in the higher watershed positions have high retention capacity with medium permeability and moderate retention capacity and permeability in the lower positions (Ministry of Environment of the SR, 2002). The watersheds (by the climatic regions of the SR) are located in climatic region C - cold in subregions: C1 - moderately cool, C2 - cool mountainous and C3 - cold mountainous (Ministry of Environment of the SR, 2002). Average annual precipitation in the watersheds range from $1037 \mathrm{~mm}$ (Pät prameňov) to $1379 \mathrm{~mm}$ (Biely Váh). Average annual temperatures in watersheds range from 0.9 (Pät prameňov) to $3.8^{\circ} \mathrm{C}$ (Biely Váh). Values of average annual precipitation and average annual temperatures are taken from the data of observation stations of the Slovak Meteorological Institute in Bratislava.

On straight stretches of each streams, we selected the reference longitudinal sections (RLS) with reference cross-sections (RCS) and determined their geometric and hydraulic characteristics according Page (1988) and Rosgen and Silvey (1996). We estabilished RLS and RCS in the terrain under the torrents sediments source zones without direct human interventions. The source zone boundary cannot be specified exactly. RLS were established in sections that well represented the overall character of the torrent bed in relatively balanced longitudinal gradient in the envisaged transport zone. We determined the geometric characteristics of the RCS by leveling. Basic characteristics of watersheds and geometric and hydraulic characteristic of RCS: width of the bed inside the banks $B_{b f}(\mathrm{~m})$, mean channel depth $H_{b f}(\mathrm{~m})$, cross-sectional area $A_{b f}\left(\mathrm{~m}^{2}\right)$

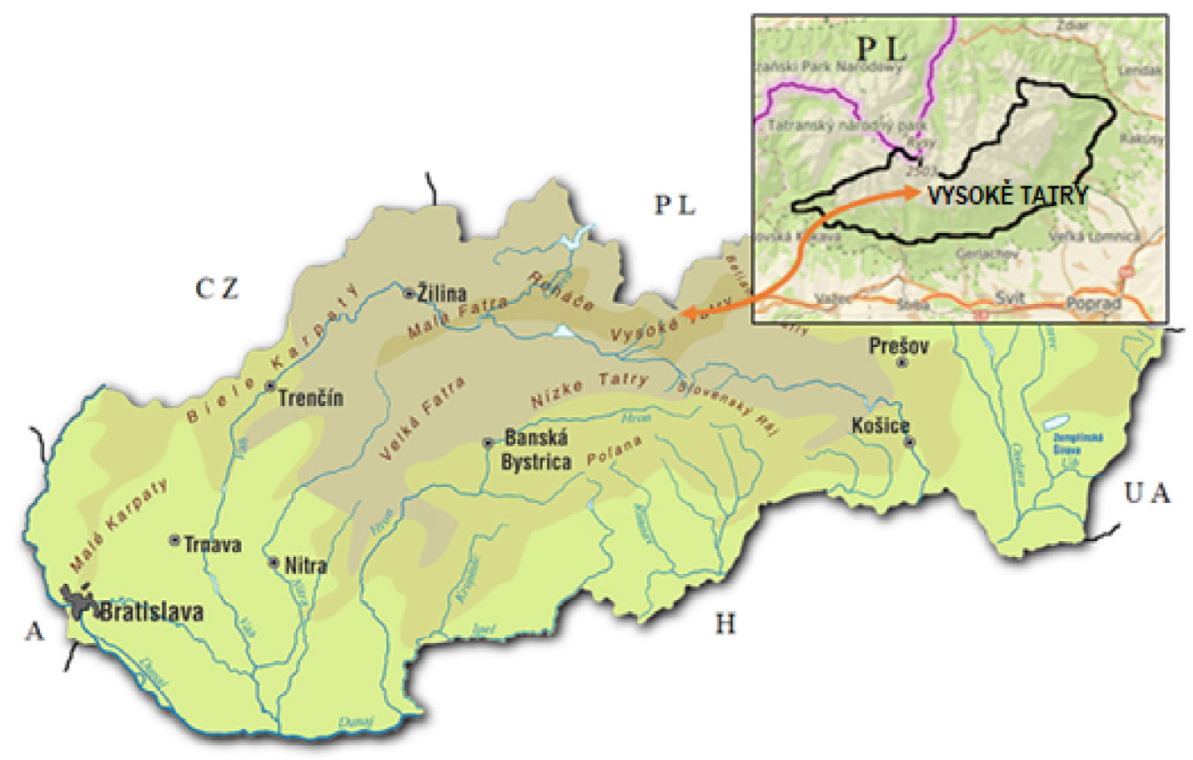

1: Map of Slovakia with designation of research watersheds area 
and bankfull discharge $Q_{b f}\left(\mathrm{~m}^{3} \cdot \mathrm{s}^{-1}\right)$ with medians of $B_{b f}=2.80(\mathrm{~m}), H_{b f}=0.55(\mathrm{~m}), A_{b f}=1.25\left(\mathrm{~m}^{2}\right)$ and $Q_{b f}=2.73\left(\mathrm{~m}^{3} \cdot \mathrm{s}^{-1}\right)$ are listed in Tab. I. To calculate bankfull discharge $Q_{b f}\left(\mathrm{~m}^{3} \cdot \mathrm{s}^{-1}\right)$, we used the Equation according to Parker (2004):

$Q_{b f}=3.732 B_{b f} H_{b f} \sqrt{g R_{b f} S}\left(\frac{R_{b f}}{D_{50}}\right)^{0.2645}\left(\mathrm{~m}^{3} . \mathrm{s}^{-1}\right)$.

The author confirmed the suitability of using equation (5) to calculate the total discharge in natural gravel beds. In the examples solved by the author, the possibilities of using equation (5) for very similar values of geometric and hydraulic characteristics, which occurred in our research, are presented. $\left(Q_{b f} \geq 2.7 \mathrm{~m}^{3} . \mathrm{s}^{-1}, B_{b f} \geq 5.24 \mathrm{~m}, H_{b f} \geq 0.25 \mathrm{~m}\right.$, $D_{50}=0.027-0.167 \mathrm{~m}, \mathrm{~S}=0.00034-0.031$, etc.).
The longitudinal slope of RLS was calculated from altitude differences of RLS determined by leveling, too. A sediment samples were collected on each RCS in order to conduct of sieve granulometric analyses used to determine the grain diameter $D_{50}(\mathrm{~m})$ with median of $D_{50}=0.102(\mathrm{~m})$. The weights of the sediment samples ranged from 52.3 to 57.2 kilograms for the individual RCS. We also determined the hydraulic radius $R_{b f}(\mathrm{~m})$ with the median of $R_{b f}=0.371(\mathrm{~m})$ during the office-run processing. Watersheds areas with up to the RCS as enclosing profiles were from the maps with GIS methods determined with median of $A_{w}=3.21\left(\mathrm{~km}^{2}\right)$.

We used the following regression Equations for analysis:

- Equation without the asymptote hitherto generally used to development of hydraulic geometry relations:

$$
y=a_{0} \times x^{a 01}
$$

I: Characteristics of watersheds and RCS to bankfull discharge calculation in High Tatras torrents

\begin{tabular}{|c|c|c|c|c|c|c|c|c|c|}
\hline Watercourse & $A_{w}$ & $\varphi H_{w}$ & $B_{b f}$ & $H_{b f}$ & $A_{b f}$ & $S$ & $R_{b f}$ & $D_{50}$ & $Q_{b f}$ \\
\hline Beliansky & 3.17 & 1614 & 3.7 & 0.65 & 2.0 & 2.85 & 0.435 & 0.141 & 4.22 \\
\hline Tri studničky & 0.36 & 1278 & 0.9 & 0.35 & 0.3 & 2.10 & 0.214 & 0.105 & 0.30 \\
\hline Mlyničná voda & 2.18 & 1544 & 2.9 & 0.55 & 1.2 & 2.77 & 0.364 & 0.091 & 2.70 \\
\hline Jamský & 0.60 & 1407 & 1.0 & 0.40 & 0.4 & 3.55 & 0.267 & 0.090 & 0.61 \\
\hline Važecký & 0.25 & 1350 & 0.8 & 0.30 & 0.2 & 2.90 & 0.154 & 0.077 & 0.24 \\
\hline Biely Váh & 10.62 & 1812 & 7.2 & 0.80 & 4.9 & 2.37 & 0.620 & 0.123 & 12.53 \\
\hline Lieskovec & 1.57 & 1434 & 2.0 & 0.40 & 0.7 & 3.90 & 0.292 & 0.152 & 1.19 \\
\hline Mlynica & 6.90 & 1740 & 4.5 & 0.65 & 1.9 & 3.93 & 0.413 & 0.129 & 5.93 \\
\hline Poprad & 19.34 & 1789 & 10.4 & 1.10 & 8.9 & 1.97 & 0.848 & 0.114 & 29.38 \\
\hline Velký šum & 4.86 & 1548 & 3.2 & 0.60 & 1.5 & 3.72 & 0.417 & 0.131 & 3.80 \\
\hline Malý šum & 3.07 & 1665 & 1.9 & 0.50 & 1.0 & 2.31 & 0.417 & 0.135 & 1.47 \\
\hline Háganský & 0.71 & 1277 & 1.0 & 0.30 & 0.3 & 3.70 & 0.188 & 0.091 & 0.35 \\
\hline Batizovský & 5.69 & 1696 & 4.5 & 0.60 & 2.0 & 3.83 & 0.417 & 0.128 & 5.45 \\
\hline Hromadná voda & 3.25 & 1510 & 2.7 & 0.50 & 1.1 & 4.20 & 0.355 & 0.093 & 2.75 \\
\hline Velický & 6.16 & 1736 & 4.5 & 0.70 & 2.1 & 3.30 & 0.404 & 0.122 & 5.83 \\
\hline Slavkovský & 5.31 & 1655 & 4.0 & 0.60 & 1.7 & 2.20 & 0.370 & 0.099 & 3.58 \\
\hline Malý Štiavnik & 0.88 & 1273 & 1.9 & 0.45 & 0.8 & 0.85 & 0.308 & 0.060 & 0.79 \\
\hline Velký Jazyk & 1.19 & 1306 & 1.9 & 0.40 & 0.8 & 2.18 & 0.348 & 0.065 & 1.21 \\
\hline Štiavnik & 1.64 & 1528 & 2.2 & 0.50 & 0.8 & 2.90 & 0.320 & 0.070 & 1.85 \\
\hline Pät prameňov & 0.98 & 1239 & 2.0 & 0.40 & 0.7 & 1.13 & 0.318 & 0.072 & 0.83 \\
\hline Pod Hrebienkom & 2.73 & 1308 & 2.6 & 0.50 & 1.0 & 1.85 & 0.345 & 0.078 & 1.80 \\
\hline Studený & 18.13 & 1793 & 9.8 & 1.10 & 7.3 & 2.63 & 0.716 & 0.400 & 20.16 \\
\hline Hlboký & 4.88 & 1304 & 2.4 & 0.55 & 1.3 & 2.53 & 0.464 & 0.069 & 2.68 \\
\hline Skalnatý & 9.37 & 1506 & 6.2 & 0.75 & 3.5 & 2.70 & 0.530 & 0.170 & 8.49 \\
\hline Kežm. Biela & 18.29 & 1612 & 9.2 & 1.00 & 6.3 & 2.78 & 0.656 & 0.115 & 23.02 \\
\hline Sedem prameňov & 4.58 & 1241 & 4.0 & 0.60 & 1.6 & 2.80 & 0.372 & 0.099 & 4.07 \\
\hline
\end{tabular}

Explanatory notes to Tab. I: $A_{w}\left(\mathrm{~km}^{2}\right)$ - watershed area; $\varphi H_{w}$ (m a.s.l.): mean altitude of the watershed; $B_{b f}(\mathrm{~m})$ - width of the RCS inside the banks; $H_{b f}(\mathrm{~m})$ - mean depth of the RCS; $A_{b f}\left(\mathrm{~m}^{2}\right)$ - RCS area; $S\left(\mathrm{~m} \cdot \mathrm{m}^{-1}\right)$ - energy gradient; $R_{b f}(\mathrm{~m})$ - hydraulic radius of RCS; $D_{50}(\mathrm{~m})$ - grain diameter; $Q_{b f}\left(\mathrm{~m}^{3} . \mathrm{s}^{-1}\right)$ - bankfull discharge 
- and newly designed Equation with the asymptote:

$y=a_{1} \times\left(1-e^{-k x}\right)+a_{11} \times x$,

$k$ - parameter expressing the stepness of regression curve to the asymptote.

\section{RESULTS AND DISCUSSION}

Characteristics of watersheds and RCS to bankfull discharge $Q_{b f}\left(\mathrm{~m}^{3} \cdot \mathrm{s}^{-1}\right)$ calculation in High Tatras torrents are listed in Tab. I.

The results and derived regional regression equations for analyzed relationships are listed in Tab. II which also contains the absolute and regression coefficients for particular regional equations.

The results were tested by t-test and ShapiroWilk test. Statistical testing by these tests and values of root mean square errors (RMSE) are listed in Tab. III. The determination coefficient $\left(R_{1}^{2}\right)$ for the relationships by regression eqation (2) without the asymptote ranged between $R_{1}^{2}=0.919$ and $R_{1}^{2}=0.972 ; p_{1}$ - values from Shapiro-Wilk test ranged between $p_{1}=0.0359$ and $p_{2}=0.8027$. The determination coefficient $\left(R_{2}^{2}\right)$ for the relationships by regression equation (3) with the asymptote ranged between $R_{2}^{2}=0.952$ and $R_{2}^{2}=0.974 ; p_{2}$-values from Shapiro-Wilk test ranged between $p_{2}=0.0221$ and $p_{2}=0.8617$. The graphical representation of the regional curves by equations (2) and (3) is shown in Figs. 2-5. Based on the results (Tab. III), we found that the determination coefficients $\left(R_{2}^{2}\right)$ for the correlation relations $B_{b f(2)}=f\left(A_{w}\right), H_{b f(2)}=f\left(A_{w}\right)$, and $Q_{b f(2)}=f\left(A_{w}\right)$ are higher than for relations $B_{b f(1)}=f\left(A_{w}\right)$, $H_{b f(1)}=f\left(A_{w}\right)$, and $Q_{b f(1)}=f\left(A_{w}\right)$; the determination coefficient $\left(R_{1}^{2}\right)$ for the relation $A_{b f(2)}=f\left(A_{w}\right)$ is almost identical to the $\left(R_{1}^{2}\right)$ for the relation $A_{b f(1)}=f\left(A_{w}\right)$. Shapiro-Wilk test (that is appropriate for the files with $n \leq 50$ ) to analyse of residuals distribution was used. We found (Tab. III) that the $p_{2}$ - values for relations $B_{b f(2)}=f\left(A_{w}\right), H_{b f(2)}=f\left(A_{w}\right)$ are significantly higher than $\mathrm{p}_{1}$ - values for relations $B_{b f(1)}=f\left(\mathrm{~A}_{\mathrm{w}}\right)$, $H_{b f(1)}=f\left(A_{w}\right)$. The $p_{1}-$ values for the relations $A_{b f(1)}=f\left(A_{w}\right), Q_{b f(1)}=f\left(A_{w}\right)$ are almost identical to the $p_{2}$ - values for the relations $A_{b f(2)}=f\left(A_{w}\right), Q_{b f(2)}=f\left(A_{w}\right)$. Based on our analysis, we can recommend the use of newly proposed regression equation (3) with the asymptote to determine of regional equations, too.

Regional curves by equation (3) with the asymptote reflects very well bankfull characteristics $B_{b f}(\mathrm{~m}), H_{b f}(\mathrm{~m}), A_{b f}\left(\mathrm{~m}^{2}\right)$ and $Q_{b f}\left(\mathrm{~m}^{3} \cdot \mathrm{s}^{-1}\right)$ especially for larger watershed areas. The importance of variant solutions in the development of regional hydraulic geometry equations and curves can be ilustrated in Fig. 3. In comparing the course of the curves

\section{II: Regression equations of analyzed relations}

\begin{tabular}{ll}
\hline \multicolumn{1}{c}{ Correlation relation } & \multicolumn{1}{c}{ Regression equation } \\
\hline$B_{b f(1)}=f\left(A_{w}\right)$ & $B_{b f(1)}=1.3366 \times\left(A_{w}\right)^{0.6787}$ \\
$H_{b f(1)}=f\left(A_{w}\right)$ & $H_{b(1)}=0.3800 \times\left(A_{w}\right)^{0.3305}$ \\
$A_{b f(1)}=f\left(A_{w}\right)$ & $A_{b f(1)}=0.3288 \times\left(A_{w}\right)^{1.0712}$ \\
$Q_{b f(1)}=f\left(A_{w}\right)$ & $Q_{b(1)}=0.4738 \times\left(A_{w}\right)^{1.3475}$ \\
$B_{b f(2)}=f\left(A_{w}\right)$ & $B_{b f(2)}=1.4676 \times\left(1-\operatorname{EXP}\left(-1.9013 \times A_{W}\right)\right)+0.45678 \times A_{W}$ \\
$H_{b f(2)}=f\left(A_{w}\right)$ & $H_{b f(2)}=0.4107 \times\left(1-\operatorname{EXP}\left(-3.9534 \times A_{W}\right)\right)+0.0359 \times A_{W}$ \\
$A_{b f(2)}=f\left(A_{w}\right)$ & $A_{b f(2)}=0.0115 \times\left(1-\operatorname{EXP}\left(-49.8164 \times A_{W}\right)\right)+0.3950 \times A_{W}$ \\
$Q_{b f(2)}=f\left(A_{w}\right)$ & $Q_{b f(2)}=-84.304 \times\left(1-\operatorname{EXP}\left(-k \times 0.0327 A_{W}\right)\right)+3.3779 \times A_{W}$ \\
\hline
\end{tabular}

III: Statistic characteristics and testing of analyzed relations

\begin{tabular}{lcccccccc}
\hline Correlation relation & $R_{1,2}$ & $R_{1,2}^{2}$ & $S_{R}$ & $t$ & $>;=;<$ & $t_{0,01(24)}$ & RMSE & $S W p_{1,2}$ \\
\hline$B_{b f(1)}=f\left(A_{w}\right)$ & 0.980 & 0.961 & 0.0403 & 24.32 & $>$ & 2.797 & 0.55 & 0.0394 \\
$H_{b f(1)}=f\left(A_{w}\right)$ & 0.959 & 0.919 & 0.0581 & 16.51 & $>$ & 2.797 & 0.06 & 0.0359 \\
$A_{b f(1)}=f\left(A_{w}\right)$ & 0.978 & 0.956 & 0.0428 & 22.85 & $>$ & 2.797 & 0.48 & 0.8027 \\
$Q_{b f(1)}=f\left(A_{w}\right)$ & 0.986 & 0.972 & 0.0342 & 28.83 & $>$ & 2.797 & 1.29 & 0.0265 \\
$B_{b f(2)}=f\left(A_{w}\right)$ & 0.984 & 0.967 & 0.0378 & 26.03 & $>$ & 2.797 & 0.51 & 0.3319 \\
$H_{b f(2)}=f\left(A_{w}\right)$ & 0.976 & 0.952 & 0.0447 & 21.83 & $>$ & 2.797 & 0.05 & 0.8617 \\
$A_{b f(2)}=f\left(A_{w}\right)$ & 0.977 & 0.954 & 0.0438 & 22.31 & $>$ & 2.797 & 0.51 & 0.7949 \\
$Q_{b f(2)}=f\left(A_{w}\right)$ & 0.987 & 0.974 & 0.0329 & 29.73 & $>$ & 2.797 & 1.27 & 0.0221 \\
\hline
\end{tabular}
Explanatory notes to Tab. III: $R_{1,2}-$ correlation coefficient; $R_{1,2}^{2}-$ determination coefficient; $S_{r}-\sqrt{\frac{1-R^{2}}{n-2}} ; t-\frac{R}{S_{r}}$; RMSE - root
mean square error; $S W p_{1,2}-$ value by Shapiro-Wilk test 
which were derived by the equation (2) withouth the asymptote and by the equation (3) with the asymptote, it is clear that for larger watershed areas, the equation (3) with asymptote significantly better reflects the relation between watershed area $A_{w}\left(\mathrm{~km}^{2}\right)$ and mean depth of the RCS $H_{b f}(\mathrm{~m})$. In other cases (in relations $A_{b f}=f\left(A_{w}\right), B_{b f}=f\left(A_{w}\right)$ and $\left.Q_{b f}=f\left(A_{w}\right)\right)$, the course of both curves is similar. For the above reasons, we propose in design optimization of geometric characteristics of channel cross sections the use of both methods, their mutual comparison and evaluation. The source zone boundary cannot be specified exactly. RLS were established in sections that well represented the overall character of the torrent bed in relatively balanced longitudinal gradient in the envisaged transport zone.

At the same time we tested the hypothesis that the correlation coefficients $R_{(1)}$ from equation (2) are only randomly different from the correlation

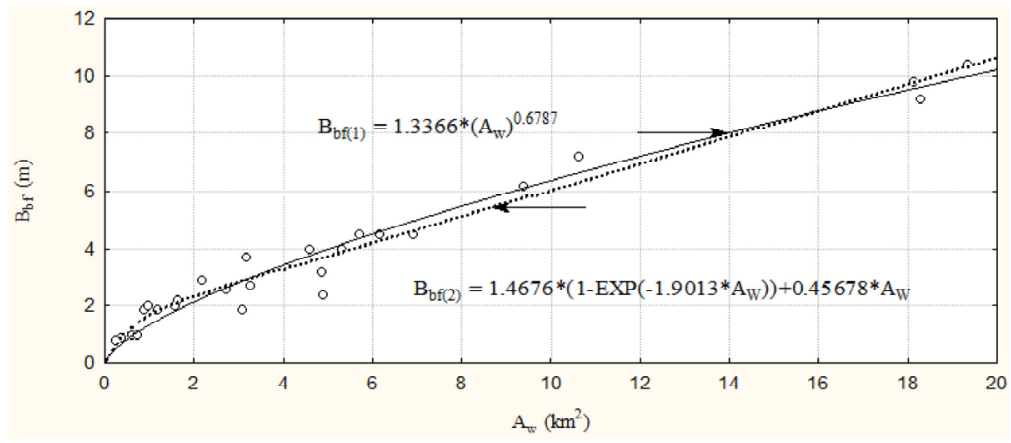

2: Regional equations and curves for the relation between $A_{w}\left(\mathrm{~km}^{2}\right)$ and $B_{b f}(m)$

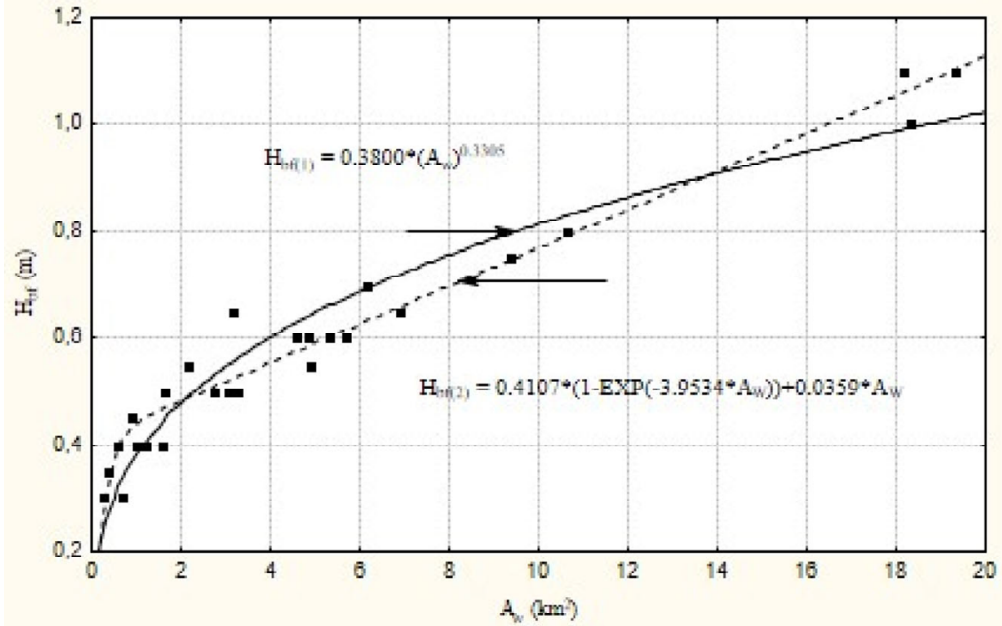

3: Regional equations and curves for the relation between $A_{w}\left(\mathrm{~km}^{2}\right)$ and $H_{b f}(m)$

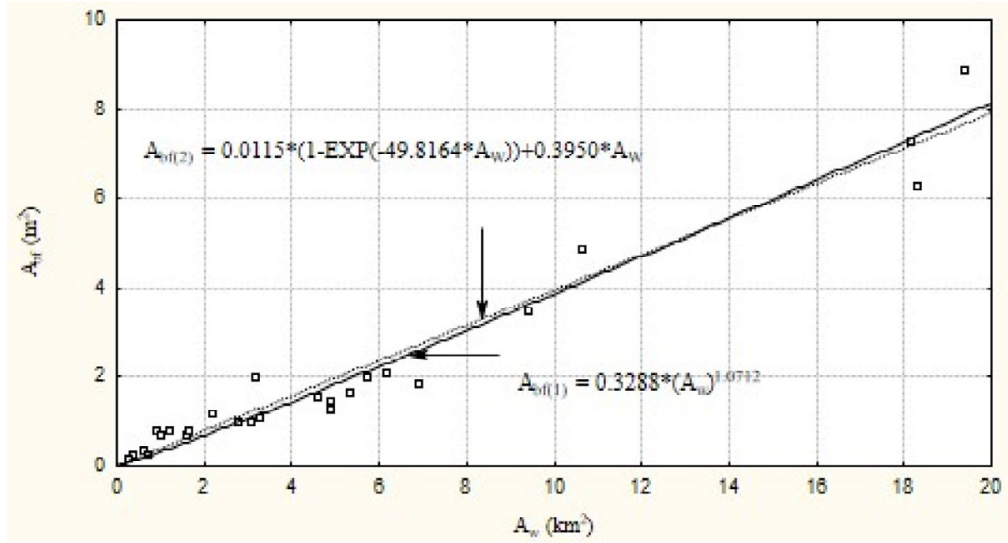

4: Regional equations and curves for the relation between $A_{w}\left(\mathrm{~km}^{2}\right)$ and $A_{b f}\left(m^{2}\right)$ 
coefficients $R_{(2)}$ from equation (3) and the difference $\left|R_{(1)}-R_{(2)}\right|$ is also random. The test criterion is the characteristic:

$Z^{\prime}=\frac{\left|Z_{R(1)}^{\prime}-Z_{R(2)}^{\prime}\right|}{\frac{1}{\sqrt{n-3}}}$.

Testing characteristics $Z^{\prime}$ are in all cases lower than the critical values $Z^{\prime}$ a. This means that we accept the hypothesis, that the differences between $R_{(1)}$ and $R_{(2)}$ are only random and therefore not significant (Tab. IV).

By permeability and resistance to water flowing in the torrent beds, Valtýni (1981) declared geomorphological value of 5 various bedrocks in the SR and confirmed that the bedrock greatly affects morphogenesis and natural geometric characteristics of torrent beds. Wolock et al. (2004) divided the USA into 20 Hydrologic Landscape regions (HLR) on the basis of similar natural characteristics. Vianello and D'Agostino (2007) evaluated variations in bankfull cross-sections along a steep stream in dolomites (Northern Italy). The relations between watershed area $A_{w}$ (from 0.040 to $7.084 \mathrm{~km}^{2}$ ) and bankfull width of the channel inside the banks $W_{b k f}$ (from 0.35 to $5.10 \mathrm{~m}$ ) were ewaluated with $R^{2}=0.620$.
Jakubis (2008) analyzed natural geometric characteristics of torrent beds on 25 torrents in a geomorphological unit of Polana (Central Slovakia, neovolcanites) with the bankfull characteristics medians of $A_{w}=4.47\left(\mathrm{~km}^{2}\right), B_{b f}=2.40(\mathrm{~m}), H_{b f}=0.55(\mathrm{~m})$, $A_{b f}=1.05\left(\mathrm{~m}^{2}\right), Q_{b f}=1.14\left(\mathrm{~m}^{3} . \mathrm{s}^{-1}\right)$ and the determination coefficients ranged between $R^{2}=0.907$ and $R^{2}=0.989$. Pšida (2014) evaluated the relationships of bankfull regional hydraulic geometry in four geographic regions - geomorphologic units in the SR with different bedrocks with the bankfull characteristics with the medians of $A_{w}=18.81\left(\mathrm{~km}^{2}\right), B_{b f}=8.10(\mathrm{~m})$, $H_{b f}=0.83(\mathrm{~m}), A_{b f}=4.53\left(\mathrm{~m}^{2}\right), Q_{b f}=8.02\left(\mathrm{~m}^{3} \cdot \mathrm{s}^{-1}\right)$ where the determination coefficients ranged between $R^{2}=0.723$ and $R^{2}=0.977$. Both authors confirmed varying and specific natural geometric and hydraulic characteristics of torrent beds and their long - term morphogenesis in watersheds with different bedrocks and natural characteristics (climate, vegetation, landform). Galia and Hradecký (2014) evaluated 120 bankfull cross-sections of 14 mountain streams in flysch bedrock of Outer Western Carpatians in the relations between watershed area $\left(A_{w}\right.$ from $0.45 \mathrm{~km}^{2}$ to $2.59 \mathrm{~km}^{2}$ ), width of the channel inside the banks ( $W_{b k f}$ from $2.17 \mathrm{~m}$ to $3.96 \mathrm{~m}$ ) and mean channel depth ( $D_{b k f}$ from 0.23 to $0.30 \mathrm{~m}$ ). Observed reaches showed a fairly good correlation $\left(R^{2}=0.53\right)$

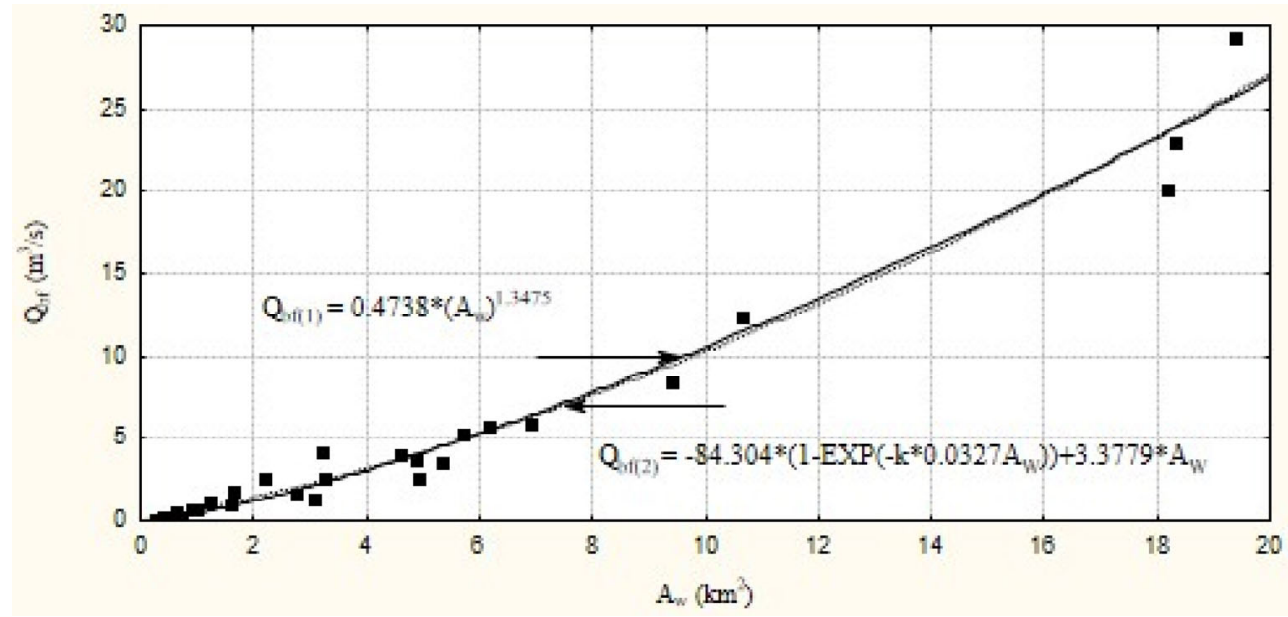

5: Regional equations and curves for the relation between $A_{w}\left(\mathrm{~km}^{2}\right)$ and $Q_{b f}\left(m^{3} \cdot \mathrm{s}^{-1}\right)$

IV: Testing of differences significance between correlation coefficients $R_{(1)}$ and $R_{(2)}$

\begin{tabular}{|c|c|c|c|c|c|c|c|}
\hline \multicolumn{2}{|c|}{ Correlation coefficient } & \multicolumn{2}{|c|}{ Fischer's transformed variable } & \multirow{3}{*}{$\frac{\left|Z_{R_{(1)}^{\prime}}^{\prime}-Z_{R_{(2)}^{\prime}}^{\prime}\right|}{3.363}$} & \multirow{3}{*}{$\frac{Z^{\prime}}{1.741}$} & \multirow{3}{*}{$\begin{array}{c}>;=;< \\
<\end{array}$} & \multirow{3}{*}{$\begin{array}{r}Z^{\prime} \alpha \\
2.807\end{array}$} \\
\hline$R_{B b f(1)}$ & 0.980 & $Z_{R B b f(1)}^{\prime}$ & 2.298 & & & & \\
\hline$R_{B b f(2)}$ & 0.984 & $Z_{R B b f(2)}^{\prime}$ & 1.935 & & & & \\
\hline$R_{H b f(1)}$ & 0.959 & $Z_{R H b f(1)}^{\prime}$ & 2.257 & \multirow{2}{*}{0.250} & \multirow{2}{*}{1.199} & \multirow{2}{*}{$<$} & \multirow{2}{*}{2.807} \\
\hline$R_{H b f(2)}$ & 0.976 & $Z_{R H b f(2)}^{\prime}$ & 2.507 & & & & \\
\hline$R_{A b f(1)}$ & 0.978 & $Z_{\text {RAbf (1) }}^{\prime}$ & 2.437 & \multirow{2}{*}{0.221} & \multirow{2}{*}{1.060} & \multirow{2}{*}{$<$} & \multirow{2}{*}{2.807} \\
\hline$R_{A b f(2)}$ & 0.977 & $Z_{\text {RAbf (2) }}^{\prime}$ & 2.216 & & & & \\
\hline$R_{Q b f(1)}$ & 0.986 & $Z_{R Q b f(1)}^{\prime}$ & 2.094 & \multirow{2}{*}{0.306} & \multirow{2}{*}{1.468} & \multirow{2}{*}{$<$} & \multirow{2}{*}{2.807} \\
\hline$\underline{R}_{O b f(2)}$ & 0.987 & $Z_{R O b f(2)}^{\prime}$ & 2.542 & & & & \\
\hline
\end{tabular}


between increasing $A_{w}\left(\mathrm{~km}^{2}\right)$ and $W_{b k f}(\mathrm{~m})$. By contrast, bankfull mean depth $D_{b k f}(\mathrm{~m})$ indicated its independence on increasind watershed area $A_{w}\left(\mathrm{~km}^{2}\right)$ with $R^{2}=0.03$. Blackburn-Lynch et al. (2017) reported results of regional equations from 2856 sites for 20 various HLR in the contiguous USA with the natural characteristics medians of $A_{w}=71.2\left(\mathrm{~km}^{2}\right), B_{b f}=10.5(\mathrm{~m}), H_{b f}=0.7(\mathrm{~m})$, $A_{b f}=7.0\left(\mathrm{~m}^{2}\right)$ and $Q_{b f}=19.5\left(\mathrm{~m}^{3} \cdot \mathrm{s}^{-1}\right)$. The determination coefficients varied from $R^{2}=0.410$ to $R^{2}=0.710$. The authors confirmed: a) the importance of regional hydraulic geometry research, b) the existence of relationships between watershed area $A_{w}\left(\mathrm{~km}^{2}\right)$ and $B_{b f}(\mathrm{~m}), H_{b f}(\mathrm{~m}), A_{b f}\left(\mathrm{~m}^{2}\right), Q_{b f}\left(\mathrm{~m}^{3} . \mathrm{s}^{-1}\right)$ and c) the differences between the regional equations and curves of hydraulic geometry for various HLR of the USA. All cited authors used to determination of regional bankfull hydraulic geometry eqations a regression equation (2) without asymptote. Different results are brought about by specific natural characteristics of each region (Powel et al., 2004). We can confirm that the regional hydraulic geometry equations provide reliable results only for specific regions and can be used in practice only in these regions from which the data originated.

\section{CONCLUSION}

Despite the fact that numerous papers are published throughout the world about regional hydraulic geometry relationships, there are very few studies focused on this problem in the SR and other countries of Central Europe. A wide range of applications of the research of regional equations in torrent control and revitalization confirm the need of further findingds in this field of science because it has not been properly addressed in Central Europe so far. Consequently, in future we can derived the regional equations of the other regions of the SR with different natural characteristics. The results of presented research can be used as an important basis for the dimensioning, design and shape optimization of cross sections of the beds in ecological torrent control within the flood protection, erosion control, revitalization and watershed management in protected area of the High Tatras region. Also, the developed equations could be used for application to other similar regions with similar natural characteristics of watersheds for example in Central Europe.

\section{Acknowledgements}

This article was supported by the Grant Agency KEGA of the Ministry of Education, Science, Research and Sport of the Slovak Republic within the project No. 006TU Z-4/2018: 3-D functional models of landscape flood protection objects as a new methods and forms of university education.

\section{REFERENCES}

ALEXANDER, J. S., ZELT, R. B. and SCHAEPE, N. J. 2009. Geomorphic Segmentation, Hydraulic Geometry, and Hydraulic Microhabitats of the Niobara River, Nebrasca - Methods and Initial Results. Scientific Investigations Report 2009-5008. Reston, Virginia: U.S. Geological Survey.

BLACKBURN-LYNCH, W., AGOURIDIS, C. T. and BARTON, C. D. 2017. Development of Regional Curves for Hydrologic Landscape Regions (HLR) in the United States. Journal of the American Water Resources Association, 53(4): 903-928.

BIEGER, K. H., RATHJENS, H., ALLEN, P. M. and ARNOLD, J. G. 2015. Development and evaluation og bankfull hydraulic geometry relationships for the physiographic regions of the United States. Journal of the American Water Resources Association, 51: 842-858.

MINISTRY OF ENVIRONMENT OF THE SR. 2002. Landscape Atlas of the Slovak Republic [in Slovak: Atlas krajiny Slovenskej republiky]. Bratislava: Ministry of Environment of the SR; Banská Štiavnica: Esprit.

DAVID, G. C. L., WOHL, E., YOCHUM, S. E. and BLEDSOE, B. P. 2010. Controls on at-a-station hydraulic geometry in steep headwater streams, Colorado, USA. Earth Surface Precesses and Landforms, 35: 1820-1837.

GLEASON, C. J. and WANG, J. 2015. Theoretical basis for at-many-stations hydraulic geometry. Geophysical Research Letters, 42(17): 7107-7114.

HOWELL, S. 2009. Development of Regional Hydraulic Geometry Curves for the Santa Cruz Mountains. San Luis Obispo: Natural Resources Management Department of California Polytechnic State University.

JAKUBIS, M. 2008. The research of relations of regional hydraulic geometry on the example of water flows of Protected Landscape Area - Biosphere Reserve Polana. Zvolen: Technical University in Zvolen.

JULIEN, P. Y. 2014. Downstream hydraulic geometry of alluvial rivers. Proc. IAHS, 367: 3-11.

LEOPOLD, L. B., WOLMANN, M. G. and MILLER, J. P. 1992. Fluvial Processes in Geomorphology. New York: Dover Publications Inc. 
PAGE, K. J. 1988. Bankfull discharge frequency for the Murrumbidgee River, New South Wales. In: WARNER, R. F. (Ed.). Fluvial geomorphology of Australia. Sydney, Academic Press, pp. 267-281.

PARKER, G. 2004. The Gravel River Bankfull Discharge Estimator. Minneapolis: University of Minnesota, National Center for Earth-surface Dynamics.

POWEL, R. O., MILLER, S. J., WESTERGARD, B. E., MULVIHILL, C. I., BALDIGO, B. P., GALLAGMER, A. S. and STARR, R. R. 2004. Guidelines for Surveying Bankfull Channel Geometry and Developing Regional Hydraulic - Geometry Relations for Streams of New York State. U. S. Geological Survey Open - File Report 03-92. New York: Troy.

PŠIDA, J. 2014. The research of regional hydraulic geometry of torrent channels in selected geomorphologic units of the SR. Ph.D. Thesis. Zvolen: Technical University in Zvolen.

ROSGEN, D. and SILVEY, H. L. 1996. Applied River Morphology. Pagosa Spring: Wildland Hydrology.

VALTÝNI, J. 1981. The contribution to classification of torrent and torrent control in Slovakia [in Slovak: Príspevok k triedeniu bystrín a bystrinných úprav na území Slovenska]. Lesnícky časopis, 27: 35-47.

WILKERSON, G. V. 2009. Improved Bankfull discharge prediction using 2-year Recurrence Period Discharge. Journal of American Ressources Association, 44(1): 243-258.

WOLOCK, D. M., WINTER, T. C. and MC. MAHON, G. 2004. Delineation and Evaluation of Hydrologic -Landscape Regions in the United States using GIS Tools and Multivariate Statistical Analyses. Environmental Management, 34(S1): 71-88.

Contact information

Matúš Jakubis: jakubis@tuzvo.sk Mariana Jakubisová: jakubisova@tuzvo.sk 